\title{
Nationalism Narrative in History Learning In Islamic Education Foundation (A Case Study of Learning History at SMA Al-Islam 1 Surakarta during the COVID-19 Pandemic)
}

\author{
Ari Prasetio ${ }^{1}$, Leo Agung ${ }^{2}$, Sariyatun ${ }^{3}$ \\ ${ }^{1,2,3}$ Universitas Sebelas Maret, Surakarta, Indonesia \\ ariprasetio679@gmail.com
}

\begin{abstract}
The Islamic Education Foundation in Indonesia has gone through several periods, from the era of the Dutch East Indies government to the present. An Islamic foundation which is quite important in the journey of nationalism in Indonesia is the Al-Islam Higher Education Foundation which was founded in 1928. The purpose of this study is to review the extent to which the SMA Al-Islam 1 Surakarta foundation is full of historical values in carrying historical learning with the narrative of nationalism. The method used is descriptive qualitative with purposive sampling technique on several teachers, staff, and students in the school environment. The results of this study indicate that the narrative of nationalism conveyed in history learning at SMA Al-Islam 1 Surakarta certainly has Islamic learning characteristics, even though it is in a conventional learning context. The teacher's background, which is equipped with scientific and distinctive Islamic studies, further encourages teachers to integrate the saga, arguments, hadiths, and ulama's fatwas into the narrative of nationalism. Interestingly, the history lessons carried out by teachers face challenges because they are faced with pandemic conditions that have hindered learning and forced schools to do online learning (online). This then deepens the studies carried out by researchers regarding the ways that teachers adapt to online learning to convey historical learning containing the narrative of nationalism in the midst of a pandemic.
\end{abstract}

Keywords

nationalismnarrative; Islamic education; SMAA-Islam1

Surakarta

\section{Introduction}

Education is key to the progress of a nation. As Iwantoro has put forward (2014:53) education is a very important issue in the development of this nation and the country. The purpose of Education is to direct the growing potential of learners to be a man of pious care to the One God Almighty, qualified, possessed of sublime pekerti ability and virtuousness. Education has a very strategic role in determining the direction of the forthcoming of the nation's quality of community knowledge. (Musdiani et al, 2019)

Education is an effective means of cultivating nationalism for students, that education has a role to strengthen nationalism and build national character. This sense of nationalism should be instilled in all the souls of the Indonesian nation, so that every society can have a sense of belonging, love the country, are willing to sacrifice, appreciate the services of heroes and prioritize the public interest (Aman, 2011). However, the process of achieving nationalism in each society has different ways according to the experiences and lessons learned. The process of cultivating nationalism can be through teaching and learning processes in schools, 
one of which is history lessons which can serve as the basis for the establishment of a national identity which is one of the main assets in building our nation today and in the future. Through teaching history, students are able to develop competencies to think chronologically and have knowledge of the past that can be used to understand and explain the process of development and change in society as well as socio-cultural diversity in order to find and foster national identity in the midst of the world's community (Agung et al, 2013).

The involvement of parents in the education of their children at school is believed to have a positive impact on the development of children or students in achieving their educational goals in schools, both academic and non-academic, which include moral, spiritual and attitude. Research conducted in Virginia shows that parental involvement has increased student success by as much as $30 \%$ when compared with low-involvement parents, while reading ability has increased by $50 \%$ more than schools with low parental commitment and involvement (Bakker and Denessen in Waluyandi et al, 2020)

According to Fauzi in Rizqi et al, (2020) learning local history is the study of the life of a particular community or community in the dynamic development of human life. Meanwhile, Warsino (2009) believes learning local history can increase a sense of concern and interest in their regional areas, to explore more deeply about anything that is on the past trajectory in their area

History learning that is used to foster the values of nationalism does not have to be centered on nationalist history material but local history can also be developed because through local history it is the basis for the development of the personal, cultural, and social identities of students (Hasan, 2012). Generally, history learning is more inclined towards conventional nationalism narratives, but what is interesting in this study is that the researcher seeks to further explore the methods used by Islamic education-based schools, more specifically SMA Al-Islam 1 Surakarta which in fact is a 'school of struggle. 'which was born from the struggle of independence figures through Islamic education with the aim of establishing the Perguruan AlIslam foundation as a stronghold of the faith of the people of Surakarta and the spirit of revolution instilled since attending school. Of course this makes researchers interested in examining more deeply.

\section{Research Methods}

The research methodology used in this study is to use descriptive qualitative research methods, qualitative research is research that is shown to describe and analyze phenomena, events, social activities, attitudes, beliefs, thoughts of a person or individual or group (Syaodih, 2005). The approach used in this research is a case study. Case study research is one of the descriptive analysis research, which is research that is focused on a particular case to be observed and analyzed carefully and thoroughly. The phenomenon that becomes the case in this research is how the narratives of nationalism built by the teacher in the learning process, especially in history learning, are in Islamic foundation schools in Surakarta. This research is a case study at SMA Al Islam 1 Surakarta. 


\section{Result and Discussion}

\subsection{Curriculum \& Learning at SMA Al-Islam 1 Surakarta}

From 1956 to 1965 students of Madrasah Aliyah Al Islam were allowed to take high school exams by joining public high schools. It was only in 1966 after SMA Al Islam 1 Surakarta received official recognition from the government, and was given full authority to hold its own examinations so that at that time the community recognized it as an AC DC school, where graduates could obtain two certificates, namely the madrasah aliyah certificate issued by the religious department. and high school diploma issued by the education department. After going through this pioneering period, the public's trust in SMA Al Islam I increased and the number of registrants enrolled in SMA Al Islam increased so that the school was divided into two, namely SMA and Aliyah, some of which entered the morning and others entered the afternoon. Then those who entered the afternoon were asked by the Ministry of Religion to become a MAN (now in Bonoloyo) in 1977 and also the teachers were made civil servants. Then there was a change of principal up to 4 times. From year to year the development of $\mathrm{Al}$ Islam was progressing, until in 1985 the status of Al - Islam I High School which was previously recognized changed to an equal status (nahdlatululama.id, 2020).

Like other schools, SMA Al Islam 1 Surakarta has a vision and mission to be achieved, namely (1) Vision: The realization of a monotheistic generation, true and steady in aqidah, scientific insight and noble character. (2) Mission: Providing sufficient basic religious education to lead students to become human beings who believe and fear Allah SWT, Carry out innovative and sustainable learning activities, Foster a spirit of excellence to all school members, Implement participatory management and the principle of deliberation, Implement extracurricular activities optimally, Building a civilized social and cultural life on the basis of brotherhood, friendship and noble morals. The application of learning at SMA Al-Islam 1 Surakarta has been going on for decades with the same character and learning principles, based on government regulations and curricula made by the government. The curriculum currently in effect by SMA Al-Islam 1 Surakarta is to use the 2013 curriculum. In addition, there is also a program of tahfidzul qur'an (Al-Qur'an Memorization Program) and recitations which are new compulsory programs that have been going on for several years. then.

The education process that takes place at SMA Al-Islam 1 Surakarta runs as the education applied in SMA in general, is based on the curriculum unit set by the Ministry of Education and Culture (Ministry of Education and Culture). It's just that, in the learning process, the application of Islamization in the realm of education is integrated with the realm of science. Religious learning is applied by including several subjects with religious characteristics such as, Syari'ah Al-Islamiyyah, Tafsir Al-Qur'an, Ulumul Hadith, SKI (Islamic Cultural History), PAI (Islamic Religious Education), Arabic, and Aqidah. In this context, the Principal of SMA Al-Islam 1 Surkarta, Umi Faizah, S.Pd., said that:

Kurikulum kami sebenarnya sudah menginduk sebagaimana ditetapkan sama Kemdikbud, hanya saja karena sebetulnya ini adalah yayasan islam, sudah seharusnya kami juga membekali para siswa dengan ilmu-ilmu agama, untuk bekalnya juga di masa depan (Interview, 20 November 2020).

Our curriculum actually has its main base as stipulated by the Ministry of Education and Culture, it's just that because this is actually an Islamic foundation, we should also equip students with religious sciences, for future provisions as well (Interview, 20 November 2020).

The implementation of religious subjects is an important requirement in the survival of Al-Islam High School, even since the beginning of the character and character of the Al-Islam college by KH. Imam Ghazali. 
The pandemic that gradually gets dissolved makes global life activities obstructed and people are faced with adapting to new habits, or what is called a new normal life. This is no exception in the implementation of education which since the 2019/2020 academic year in the second semester (March 2020), has been transferred to online learning. The government issues policies simultaneously to divert learning with learning patterns that focus on using online technology. Even though later there were still some obstacles that were encountered, considering that this kind of learning pattern is a novelty in the world of education.

Entering the pandemic period, learning patterns must undergo significant changes, where teachers and students do not meet each other directly but continue to provide education. The learning process at Al-Islam High School uses many platforms that can be used as virtual classes, starting from Google Classrom, Office 365 Class, to the simplest is Whatsapp. The teacher makes material to be uploaded and can be accessed (read) by students as a stimulus, then it is followed up with the application of a simple learning model through the chosen platform (Susmiati, 2020).

\subsection{Narrative of Nationalism in Learning History at SMA Al-Islam 1 Surakarta}

Historical learning is actually loaded with the values contained in it, more specifically nationalism. In the content of the narrative of nationalism in history learning, it can be found in many chapters of textbooks that are scattered in schools, and even become a reference source or reference recommended by the Ministry of Education and Culture (Kementrian Pendidikan Budaya). The value of nationalism is an important element for history subjects, even the narrative of nationalism becomes the spirit that makes history a meaningful learning, and has an important position in building the nation's civilization. This role is what makes history still a part of a scientific discipline that still has an existence to be conveyed and absorbed properly by students.

The narrative of nationalism in the context of education, especially in history learning, converges on the understanding of teachers in interpreting and embodying the narrative of nationalism as an element that does not escape history learning. Especially in the periodization of Indonesia in the era of the national movement, it became a turning point for the emergence of nationalism in Indonesia, where in this era it was mostly studied in the eleventh grade (XI or 2 SMA / equivalent). In this context, Galih Pranata, M.Pd., as a history teacher stated that:

$Y a$, di kelas XI sangat banyak memang materi yang berkaitan dengan nilai nasionalisme, malah semua materi sejarah Indonesia di kelas XI banyak menceritakan gelora nasionalisme yang diperankan oleh tokoh-tokoh sejarah (Interview, 18 November 2020).

Yes, in class XI there is indeed a lot of material related to the value of nationalism, in fact all of the material on Indonesian history in class XI tells a lot about the passion of nationalism played by historical figures (Interview, 18 November 2020).

The reading of nationalism is clearly written and compiled by the AGSI (Association of Indonesian History Teachers) together with the MGMP (The Discussion of Teachers' Forum) teachers of History to determine the narratives of nationalism in the era of the Indonesian nation's struggle in class XI SMA / equivalent. The turning point of nationalism is known to be the response of colonialism which occurred for several years, or even centuries, the Indonesian nation was afflicted with suffering because of the cruelty and injustice of the colonial government. On the other hand, after being able to wrest independence from the shackles of colonialism, the Indonesian nation was again tested for its nationalist attitude when the Dutch and the Allies again attempted to control Indonesia. In this period of struggle, everything was packaged in one learning scope, Indonesian history at the XI SMA / equivalent. In this context, Ahmad Rushanficry, S.Pd. add that : 
Ranahnya tentu berbeda, konteks kajian juga berbeda antara sejarah peminatan dan sejarah Indonesia, atau bisaanya disebut sejarah wajib di kelas XI. Bisaanya, sih, sejarah peminatan ruang lingkupnya meliputi tidak hanya Indonesia, tetapi juga pengaruh internasional, seperti peristiwa-peristiwa penting di dunia (Interview, 19 November 2020).

The realm is of course different, the context of the study is also different between the history of specialization and the history of Indonesia, or what could be called compulsory history in class XI. It could be that the history of the specialization includes not only Indonesia, but also international influences, such as important world events (Interview, 19 November 2020).

The selection of Indonesian History (Mandatory) class XI subjects as a reading of nationalism narratives is actually determined based on the suitability of $\mathrm{KD}$ and teaching materials which contain more elements of nationalism. The narrative of nationalism is actually quite visible in almost every KD (Basic Competency). The KD which can be a study in the narrative of nationalism includes:

Table 1. KD History of Indonesia Class XI related to the Narrative of Nationalism

\begin{tabular}{cl}
\hline KD & \multicolumn{1}{c}{ Materi } \\
\hline 3.1 & Development of European Colonialism and Imperialism \\
3.2 & The Impact of European Occupation for the Indonesian Nation \\
3.3 & Education and National Movement \\
3.4 & Japanese occupation of Indonesia \\
3.5 & National and Regional Figures in Fighting for Independence \\
3.6 & Proclamation of Indonesian Independence \\
3.7 & The Struggle to Defend Independence from the Threats of the \\
& Allies \& the Netherlands \\
\hline
\end{tabular}

Starting from KD 3.1 which in the 2013 curriculum is held in the first semester up to 3.7 which is held at the end of the school year (semester two) on the subject of Indonesian history, full of nationalism narratives. In detail, the narrative of nationalism can be seen from several basic competencies and teaching materials.

In teaching materials that contain nationalism, it can be said that the narrative of nationalism has begun to appear in material 3.3, Education and National Movements. The narrative begins when the Queen of the Netherlands, Queen Wilhelmina orders the government in the Indies to implement ethical politics. Ethical politics is a thought which states that the colonial government held moral responsibility for the welfare of the bumiputera. This thinking is a critique of the politics of forced cultivation. The emergence of Ethics was spearheaded by Pieter Brooshooft (De Locomotief Newspaper journalist) and C.Th. van Deventer (politician) apparently opened the eyes of the colonial government to pay more attention to the fate of the backward bumiputera.

Ethical political policies consist of irrigation, building and repairing irrigation and dams for agricultural purposes. Immigration, namely inviting residents to transmigrate, and Education, namely expanding in the field of teaching and education. The influence of ethical politics in the field of teaching and education was instrumental in the development and expansion of the world of education and teaching in the Dutch East Indies. From this it became the forerunner to the emergence of educated people from the bumiputera who would later fuel the ideas of nationalism.

The ethical politics that gave birth to a generation of bumiputera who had a passion for intellectuality, led to the era where the idea of nationalism was being promoted, the period of 
national movement in Indonesia. Nationalism grew in Indonesia starting after the emergence of Islamic Unions. Budi Oetomo, which was formed earlier, was an "elite" organization so that it did not contribute to fostering nationalism throughout society. The Islamic Union made various efforts to foster nationalism throughout the Dutch East Indies at that time. Due to the supporting factors above, the spirit of nationalism has begun to emerge in Indonesia.

The spirit of nationalism is used as an ideology / understanding for the existing national movement organizations. The National Ideology in Indonesia was introduced by the Indonesian National Party (PNI), chaired by Ir. Soekarno. PNI aims to fight for the life of the Indonesian nation that is free from colonialism. Meanwhile, the goal is to achieve an independent and sovereign Indonesia, and to expel the Dutch colonial rule in Indonesia. With Nationalism being used as an ideology, it will show that a nation has the same culture, language, region as well as goals and ideals, thus fostering a deep loyalty to the nation group.

Especially in the narrative of nationalism it is associated with Islamic nuances and is also inseparable from school history. The Surakarta Al-Islam College was originally born on March 21, 1928 by KH. Imam Ghozali was assisted by KH Abdussomad and KH Abdu Manaf. The establishment of the Al-Islam college was none other than to create a spirit of learning Islam, even though it had to deal with a number of policies set by the Dutch East Indies government. Initially, the College of Al-Islam was called Dinul Islam which only opened the Ibtidaiyah school in the afternoon and Tsanawiyah in the morning. Your curricula has a tendency towards Islamic religious studies. The increasing enthusiasm of the people who came to learn and were encouraged by the wahdatul ummah (community unity) and the Qur'an and Sunnah movement in 1932 the Dinul Islam madarasah was changed to Al Islam with the constitution (1933 / M / $1351 \mathrm{H})$.

The 1936 Congress saw a change in the composition of the new board, so that activities were not solely educational but developed into the fields of Da'wah, Scouting Al-Wathoni, and Youth (Subhanul Muslimin) while the women's movement was called Nahdlotul Muslimin (NDM). Furthermore, in 1948 the Islamic education congress in Surakarta was mandated to include general lessons in the madrasa curriculum, then on the initiative of KM Makmuri the curriculum was compiled as intended, so that MA Al Islam, which originally had 2 years of study became 3 years due to additional general lessons of the same with high school.

In 1965, several foundations' leaders filed applications for equal status permits to be equal to public schools. However, these attempts failed because they had to adjust to middle or high school or PGA. Imam Ghozali faced Syaifudin Zuhri, who at that time was the minister of religion and also an alumnus of Madrasah Al Islam. Not stopping there, Imam Ghozali continued to propose through Dipenda Bp. Mulyadi Marto Sudarmo, who in 1967 asked to be converted into or changed to PGA, which was finally approved by the congregation of Al-Islam on condition that they continue to use the Al-Islam curriculum. School leaders are appointed by the suggestion of Al-Islam. The appointment of teachers was discussed with Al-Islam. AlIslam Negeri Tsanawiyah Madrasah was established.

Historical learning that links the narrative of nationalism with Islamic characteristics in it becomes the identity of learning patterns that have been built since Al-Islam was first founded. Even though it is in a virtual learning condition like today, the implementation of education must still be carried out as well as possible. Some of the results of the media developed are associated with Islamic nuances, for example, the learning video media uploaded to the Youtube channel of SMA Al-Islam 1 Surakarta, by Ahmad Rushanfichry, S.Pd., which explains the background of the arrival of Europeans to Indonesia. 


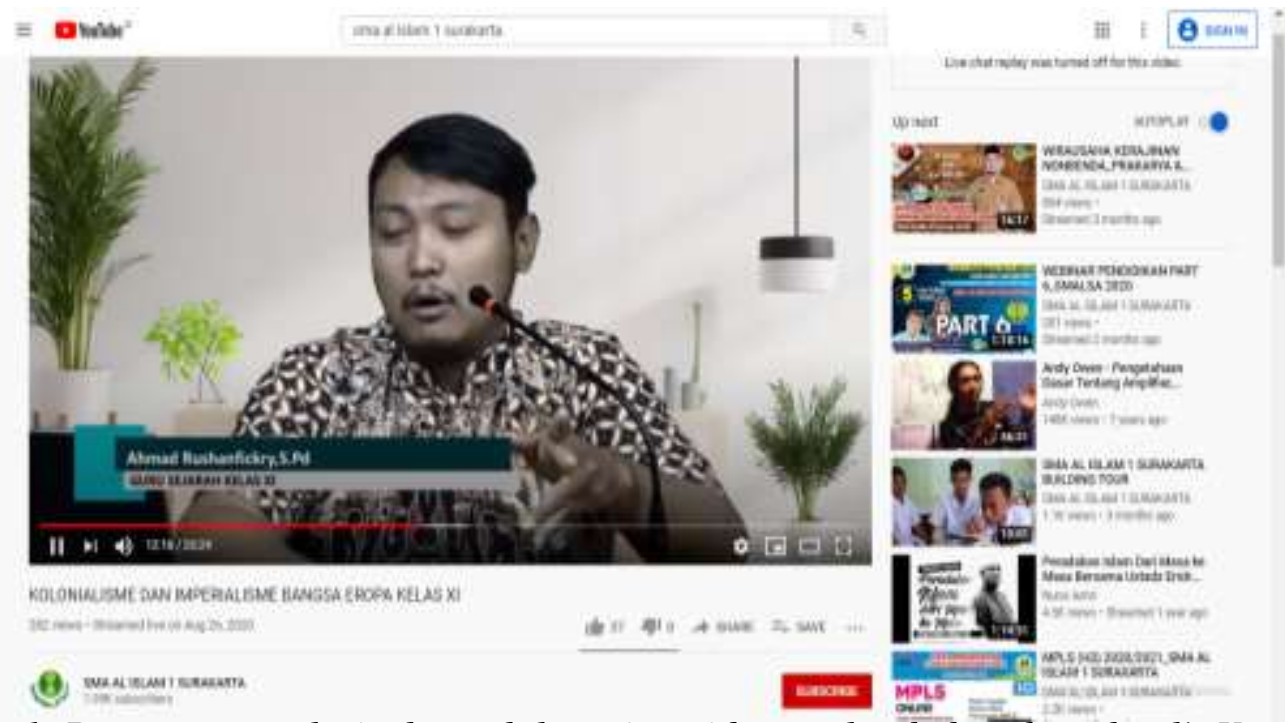

Figure 1. Document analysis through learning videos uploaded to the school's Youtube channel

This is then associated with the spirit of nationalism shown by the narrative of the nationalism of Sultan Murad II or Al-Fatih in upholding the sentence of Allah, by destroying the solid wall of Constantinople and controlling it after going through months of struggle for siege. This then became the background for European exploration in finding new lands and paving the way for European imperialism.

The use of learning media is also the most effective alternative to do, especially through platforms that are being favored by students, such as through the Youtube platform. Through the Youtube platform, the school took the initiative to create instructional media that was able to explore teacher competencies in delivering material and provide clear understanding for students.

Researchers try to trace the extent to which history teachers can understand the narrative of nationalism which is certainly inseparable from Islamic characteristics. In this case, the authors found that there is a routine school review agenda that teachers must follow and discuss many things. This study is called Imama and At-Tijan, which in general discusses the main points of study in Islam which are quoted from the arguments of the Al-Qur'an and Sahih Hadith, one of the themes that have been touched on several times in this study is about nationalism in Islamic perspective.

As for the study of nationalism which is provided directly by schools, several important books on the history of Al-Islam colleges are also available in the school library. Like one of the books entitled Perserekat Al-Islam, by Rachmad Abdullah. The book contains many narratives of al-Islam's journey in upholding Islam in order to create a nationalist generation with Islamic character. This book was lent to teachers and students to become a means of socializing school history, reflecting the characteristics of the school based on the history of the development of SMA Al-Islam 1 Surakarta from time to time. From here it can also be seen that the cultivation of nationalism is carried out through school policies so that teachers are equipped with the spirit of nationalism. 


\section{Conclusion}

Historical learning is actually loaded with the values contained in it, more specifically nationalism. The narrative of nationalism in the context of education, especially in history learning, converges on the understanding of teachers in interpreting and embodying the narrative of nationalism as an element that does not escape history learning. Especially in the periodization of Indonesia in the era of the national movement, it became a turning point for the emergence of nationalism in Indonesia, where in this era it was studied more in the eleventh grade. In teaching materials that contain nationalism, it can be said that the narrative of nationalism has begun to appear in material 3.3, Education and National Movements. Historical learning that links the narrative of nationalism with Islamic characteristics in it becomes the identity of learning patterns that have been built since Al-Islam was first founded. Even though it is in a virtual learning condition like today, the implementation of education must still be carried out as well as possible. The use of learning media is also the most effective alternative to do, especially through platforms that are being favored by students, such as through the Youtube platform.

\section{References}

Aman. (2011). Model Evaluasi Pembelajaran Sejarah. Yogyakarta: Ombak

Agung, Leo dan Sri Wahyuni. (2013). Perencanaan Pembelajaran Sejarah. Yogyakarta: Ombak

Hasan, Hamid. (2012). Pendidikan Sejarah Untuk Memperkuat Pendidikan Karakter. Jurnal Paramita. 22(1).

Kohn, Hans. (1965). Nationalism Its Meaning and History. Malabar Florida: Robert E. Krieger Publishing Company

Kartodirdjo, Sartono. (1994). Fungsi Pengajaran Sejarah dalam Pembangunan Nasional. dalam Historika. Surakarta UNS

Musdiani, et al. (2019). Analysis the Role of Headmaster in Applying Quality of Education in Primary School Districts, Aceh Barat. Budapest International Research and Critics in Linguistics and Education (BirLE) Journal. P. 27-35.

Rizqi, Y. et al. (2020). Development of Local History Learning with the Heroism Theme of K. Gholib Based on E-Book for Private Vocational School Students in Pringsewu Regency. Budapest International Research and Critics in Linguistics and Education (BirLE) Journal. P. 1287-1300.

Syaodih, Nana, Sukmadinata. (2005). Metode Penelitian Pendidikan. Bandung: Remaja Rosda Karya

Susmiati, Eri. (2020). Meningkatkan Motivasi Belajar Bahasa Indonesia Melalui Penerapan Model Discovery Learning dan Media Video Dalam Kondisi Pandemi Covid-19 bagi Siswa SMPN 2 Gangga. Jurnal Paedagogy: Jurnal Penelitian dan Pengembangan Pendidikan. 7(3), pp.210-215

Waluyandi, F., et al. (2020). Implementation of Parental Involvement in Learning Civic Education. Budapest International Research and Critics in Linguistics and Education (BirLE) Journal. P. 1686-1695. 